\title{
The Relevance of Financial and Non-Financial Compensation on Professionalism and Lecturers Performance: Evidence from Makassar Private Universities (Indonesia)
}

\author{
Muhammad Hamzah Idris (Corresponding author) \\ PhD Candidate, Postgraduate School of Economics University of Hasanuddin \\ Makassar, Indonesia \\ E-mail: hamzah.idris.4580@gmail.com
}

Djabir Hamzah, Indrianty Sudirman \& Nurdjanah Hamid

Faculty of Economics and Business, Hasanuddin University

Makassar, Indonesia

Received: June 2, 2017 Accepted: July 10, $2017 \quad$ Published: July 11, 2017

doi:10.5296/jad.v3i2.11491 URL: https://doi.org/10.5296/jad.v3i2.11491

\begin{abstract}
This study aimed to test empirically the effect of financial and non financial compensation on professionalism and lecturer's performance. The study population was all lecturers who are certified, public and private lecturers at the private universities in Makassar (Indonesia). Stratified proportional random sampling was used to obtain the total sample of 111 lecturers'. Covariance-based SEM (SEMPLS) with a WarpPLS 5.0 used in this study. The results of the study provide evidence that financial and non financial compensation has a positive and significant effect on the lecturer's professionalism. Financial compensation has a positive and significant effect on the lecturer performance but non financial compensation did not. The level of professionalism has a positive and significant effect on the lecturer's performance. Professionalism can be evident as a mediating role in explained effect of financial and non financial compensation on lecturer's performance.
\end{abstract}

Keywords: Financial, non financial compensation, professionalism, lecturer's performance 


\section{Background}

Lecturer is an asset owned by universities as lecturers are professional educators and scientists with the main task of transforming, developing and disseminating science, technology, and art through education, research, and community service. The central role requires lecturers to improve professionalism in continuously through the activities of the Three Pillars of Higher Education Comprising Education, Research and Community Service. Professionalism is related to two important aspects, namely the structural aspect and the aspect of attitude. Structural aspects are part of the establishment of the training, professional associations and the code of conduct. While the attitude aspect relating to the establishment of the professional aspect (Hall, 1968).

Professionalism is a concept to measure how a professional look at the profession as reflected in the attitudes and behaviour (Dali et al., 2013). Every professional has a professional identity; the question is how conscious and purposefully chosen it is. It is impossible to imagine a professional without a professional identity; but it is possible that professionals cannot articulate their professional values and commitments hence cannot purposefully draw on the core of their identity. Identifying with values and moral principles often remains tacit and non-conscious (Nystrom, 2009). As work integrated learning scholars, it is our role to prepare students for their future work roles. Work role preparation includes not only disciplinary knowledge and technical skills but also intelligence about how to work in a team, communicate with others, and learn tacit ways of working through observations and socializing into workplace cultures. Helping students develop a sense of professional identity and engage with issues of professionalism can enhance workplace learning experiences

Professional attitude or professionalism can be defined as the growing qualification of specific knowledge and accompanied by a code of ethics (Gibbs, 1994). Apart from the knowledge and code of ethics, professionalism also refers to an attitude that represents the level of identification with a commitment to a particular profession (Wayne \& Youngs, 2003). Professional lecturers are those who are always reliable, responsible, diligent, disciplined and serious in carrying out their obligations. Professional individuals who identified with quality, commitment, responsibility, and high compensation (Uno \& Lamatenggo, 2012), it distinguishes by an amateur to do a job. Individuals who are amateurs, in carrying out its obligations very constituted by a sheer pleasure, superficial knowledge, and also the lack of morality and responsibility against what was done (Harefa, 1999).

Past research shows that professionalism is the antecedent of individual performance and influence indirectly through opportunities to accumulate knowledge of the work (Schmidt \& Hunter, 1998). The study of professionalism is also done in the world of education, that the criteria of professional individuals in the context of educational institutions have been analyzed quantitatively. Some studies show that the dimensions for measuring the professionalism of someone who consist of an undergraduate degree, licensure, or in other words the ability of faculty to certify and job tenure indicate a relationship that is statistically significant with the achievement of students (Darling-Hammond, 2000; Omenn Strunk \& Robinson, 2006). Although the study found a positive result but not all researchers agree with 


\section{Ml Macrothink}

these results, in fact there are some researchers oppose these findings (Kaplan \& Owings, 2001; Wayne \& Youngs, 2003) inclined not find a relationship between the dimensions and indicators such as a degree, licensure, and job tenure to the achievement of the students he taught.

Motivation has a significant effect on terms of professionalism and individual performance (Bellois, 2003) The relationship between motivation, especially in the provision of compensation of non-financial with a professional attitude in improving the performance shown in studies Thomson \& Strikland (2001), the findings of the study proved that the Japanese company i.e. successful, employees meet regularly for professional dialogue and recite the professional rules, one of the most motivating factors untapped is a shame that will create a professional attitude and values towards belief in doing the best job in the profession. Opportunity for recognition, power, social status, prestige, security, growth and development in their careers as well as good leadership is far more important than the money that can influence the performance of the individual.

Motivational factors focused on financial compensation as well as non-financial compensation to give significant effect on professionalism and performance (Nzulwa, 2014). Compensation granted to employees can provide a positive impact on performance improvement towards a better (Surbakti, 2011; Hameed et al., 2014; Tanjung, 2015). Discourse studies that contradict the results of the above in view of the influence of financial compensation to the performance shown in the study by Sofyan (2012) that partial certification benefits no effect on performance improvement. Universities in Indonesia are the main focus in creating quality graduates. To achieve this goal the college is required to have the infrastructure, curriculum, as well as good governance and the most important is the quality of human resources, especially lecturers who are competent in their field, and this is because the quality of a teacher is instructive is the key to success a formal educational institution (Burki, 1999; Angrist, 2001). To achieve quality performance, a lecturer is required to act professionally in doing any work that is given to him. Under these conditions, the government through the Law of the Republic of Indonesia Number 14 of 2005 confirms the position of a professor as professionals who can be given the recognition of professional lecturers as can be evidenced through certification allowance provision (Chapter 2, Article 3, paragraph 2). This certification is done by the government to lecturers undertaken to enhance the dignity of lecturer's and also as a form of government recognition that the lecturers are lecturers are professionals in their field.

Professional lecturer certification to a person in a profession, who, by virtue of academic degrees and professional expertise has developed special knowledge, professional lecturer certification as a form of non-financial rewards and benefits of certification as a form of monetary rewards expected to be able to motivate faculty to improve the professionalism of lecturers and maximize performance. The fact that the case showed, the certification allowance has been unable to give a significant effect on lecturer's performance improvement, which has been certified. A benefit of certification does not give effect to the improved performance. Under these conditions, it is in addition to interference from the government through the provision of benefits and certification to maximize the performance of lecturers, 
the role of universities is needed to contribute to the establishment of professionalism and maximizing the lecturers performance (Sofyan, 2012). Lecturers performance at a private university in Makassar tend to be low, lecturer still perform his duty well, it is reflected on the fulfillment of faculty workload is the reference of faculty performance ratings as a form of implementation of the implementation of the Three Pillars of Higher Education Comprising Education, Research and Community Service (Alma, 2015). Revealed that the private universities in Makassar there are lecturers who teach under 12 Semester credit system per semester, besides there are also lecturers who hour of teaching beyond the realm of system credit per semester predetermined specified by the Indonesian Ministry of Research, Technology and Higher Education (Rusydi, 2014; Alam, 2015).

\section{Literature Review}

\subsection{Financial Compensation}

Compensation is defined as something that is acceptable in lieu of individual contribution to the organization of their services (Rivai, 2011). Compensation refers to all forms of wages or compensation that apply to and emerge from their work, and have two components. There is a direct payment in the form of salaries, wages, incentives, commissions, and bonuses, and there is an also indirect payment in the form of financial benefits such as insurance and vacation money (Dessler, 1998). Financial compensation consists of (1) Direct financial compensation which is a form of cash payments received directly in the form of salary/wages, economic benefits, bonuses and commissions. Salary is the remuneration paid periodically to the individuals to stay and have a final guarantee, while wages are the remuneration paid to workers by referring to the agreement agreed upon payment, and (2) Indirect financial compensation is the entire award excluding financial direct compensation. Forms of indirect compensation programs include employment insurance, social assistance, payment of medical expenses and others (Dessler, 1998; Mondy 2008).

Meeting the needs of both by financial and non-financial has become a motivation for each employee to do the job it is doing. For that purpose, the compensation must be managed properly by the organization so that organizational goals can be achieved through individual performance (Riva, 2011). Measurement of financial compensation constructs used to develop by Yousaf et al. (2015), namely; salaries, incentives, insurance planning, social assistance. Compensation provides a positive influence on performance improvement (Sofyan, 2012; Tanjung, 2015).

Inconsistency indicated at Sofia (2012), that the partial certification of lecturers, education and training does not affect the performance improvement of lecturers. Polemic research shows that the compensation system: (1) leads to job behaviours dysfunctional, (2) make the work behaviour functionally ineffective and even discourage it, (3) are focused on the work of each employee compared to strengthen the cooperation between employees, (4) making employees is difficult to have the perception that a clear and unambiguous to the relationship between the performance of the award he received, (5) although it is intended to pay for performance, but in reality intended to pay employee attendance, (6) directing employees to behaviours they believe will enable awarded, where these behaviours are often incompatible 
with the desired employee behaviour by the leadership (Kerr, 1975) financial compensation providing a positive influence to the professionalism (Nzulwa, 2015; Tanjung, 2015).

\subsection{Non Financial Compensation}

Non financial compensation within an organization is a reciprocal form of awards in the achievement of the performance. Although the non financial compensation of an award does not have a lot of theoretical basis as financial compensation, we believe that the conceptual differences between the awards that are financial and non-financial is important (Peterson \& Luthans, 2006). Non financial compensation is remuneration from universities. Compensation of this type can be divided into: (1) Non financial job, the job can be an interesting job, a chance to flourish, training, awards for his performance, and promotion. This form of compensation is the realization and fulfilment of self-actualization, (2) Non financial is a compensation related to the work environment. Non-financial compensation regarding the work environment can be supervisory competence, comfortable working conditions, and job sharing (Mondy, 2008: 442).

Non financial compensation split into two major sections that include non financial compensation into sub-variables. In the non-financial compensation on a career covering secure in position, promotion opportunities, recognition of work, the new findings, and a special achievement. While on compensation related to the work environment include duty comfortable (Rivai, 2011). Non financial compensation is an award that focuses on the need for employees to get a rate that varies in achievement, recognition, responsibility, influence and self-development (Armstrong, 1999).

A survey was conducted to ask the employees provide value to the various awards; it was found that the non-financial rewards are in place higher than financial reward (Luthans, 2005). Measurement of non-financial compensation constructs used to develop by Akhter et al. (2016), include; awards, promotion and working conditions that support social recognition and performance feedback significantly improves performance relatively higher than the salaries of traditionally managed performance (Stajkovic \& Luthan, 2003). Studies comparing the compensation of financial and non financial found that financial incentives have a greater effect on the value of benefits, customer service, and employee retention results. But in addition to financial compensation for employee retention and non-financial compensation impact balanced significantly (Peterson \& Luthans, 2006). The provisions of non financial compensation are proven to increase performance (Akhter et al., 2016).

\subsection{Professionalism}

Professionalism is related to two important aspects, namely the structural aspect and the aspect of attitude. Structural aspects are part of the establishment of the training, professional associations and the code of conduct (Hall, 1968). Professionalism concept used to measure how professional a person to his profession as reflected in the attitudes and behaviour (Dali et al., 2013).

There is a reciprocal relationship between attitudes and behaviour. Professional behaviour is a reflection of the professionalism and vice versa (Hall, 1968; Kalbers \& Fogarty, 1995). 
Professionalism refers to the attitude that represents the level of identification as well as a commitment to a particular profession (Wayne \& Youngs, 2003). Several studies conducted to determine the positive effect of professionalism on performance, which means that with the increased professionalism of employees will provide a significant impact to performance (Kwon et al., 2010; Dali \& Mas'ud, 2014; Schmidt \& Hunter, 1998).

Lecturer professionalism are not only related to the mastery of a discipline and a certain expertise, but also required best practice in education, research and dedication to public service. Thus a professional lecturer has a role not only doubles but multi, which constantly maintain and develop professionalism in the field of knowledge and expertise, as well as trying to understand and improve the satisfaction of the academic community as stakeholders college (Arwildayanto,2013). The construct of the variables used in measuring lecturer professionalism, include; Organization affiliation, belief in public service, belief in self-regulation, sense calling on the field, and autonomy (Boyt et al., 2001) The study of professionalism in the structural aspects of the show that dimensions for measuring the professionalism of someone consisting of bachelor's degree, licensure or in other words is certified, a faculty member in the profession, and the length of his experience shows the correlation is statistically significant with their achievement they teach or students (Darling-Hammond, 2000). Professionalism has a significant effect on performance (Kwon et al., 2010; Dali \& Mas'ud, 2014).

\subsection{Lecturer's Performance}

Performance is the functions required of a person, the performance is an act, an expression, or what is shown through the skill of a real person (Whitmore, 1997: 104). Borman \& Motowildo (1993) divides the two parts of the performance based on the performance of the task and contextual performance. While the performance of contextual activities that do not pertain directly to the work but have an influence on the organizational environment, social, and psychological to be achieved within an organization. One example of this contextual performance may be giving advice, or giving the rock to colleagues in achieving an organization (Alam, 2015).

The construct of lecturer's performance, include; education and teaching, research and development and dedication to the community (Nature, 2015). Several studies have revealed that the provision of financial compensation has been able to increase the professionalism of the employees (Nzulwa, 2014; Tanjung, 2015). Non-financial compensation was given to employees to improve performance towards better (Peterson \& Luthans, 2006; Yousaf et al., 2014).

\section{Methods}

The study population was all lecturers who are certified, public and private lecturers at the private universities in Makassar (Indonesia). Stratified proportional random sampling was used to obtain the total sample of 111 lecturers. Covariance-based SEM (SEMPLS) with a WarpPLS 5.0 developed by Kock (2010) used in this study. 


\section{Results}

\subsection{Description of Respondents}

Identity of respondents such as gender, age, level of education and working life, served to determine the number of frequencies and percentages of respondents' representative presence in response. Shown as follows:

Table 1. Respondents

\begin{tabular}{|c|c|c|c|}
\hline \multicolumn{2}{|c|}{ Characteristics of respondents } & \multirow{2}{*}{$\begin{array}{l}\text { Frequency } \\
(n=111) \\
98\end{array}$} & \multirow{2}{*}{$\begin{array}{l}\text { Percent }(\%) \\
88,29\end{array}$} \\
\hline & Male & & \\
\hline Gender & Female & 13 & 11,71 \\
\hline \multirow{5}{*}{ Age (years) } & $<35$ & 21 & 18,92 \\
\hline & $35,1-45$ & 23 & 20,72 \\
\hline & $45,1-55$ & 46 & 41,44 \\
\hline & $55,1-65$ & 17 & 15,32 \\
\hline & $>65$ & 4 & 3,60 \\
\hline \multirow{2}{*}{ Education } & Masters program & 71 & 63,96 \\
\hline & Doctoral program & 40 & 36,04 \\
\hline \multirow{5}{*}{ Years of work experience } & $05-10$ & 23 & 20,72 \\
\hline & $11-15$ & 29 & 26,13 \\
\hline & $16-20$ & 31 & 27,93 \\
\hline & $20-25$ & 23 & 20,72 \\
\hline & $>25$ & 5 & 4,50 \\
\hline \multirow{4}{*}{ Functional positions } & Instructor & 23 & 20,72 \\
\hline & Assistant Professor & 42 & 37,84 \\
\hline & Associate Professor & 43 & 38,74 \\
\hline & Professor & 3 & 2,70 \\
\hline
\end{tabular}

The table shows that the frequency of respondents by sex is characterized it is 98 male (88.29\%). Most of the respondents had ages between 45.1 to 55 years $(41.44 \%)$, with the majority levels of education the masters program (63.96\%), as well as working period 16-20 years $(27.93 \%)$ and has a functional position as associate professor (38.74\%).

\subsection{Test Goodness of Fit Model}

P-value for the average path coefficient (APC) and the ARS and the R-squared value Average (ARS) must be $<0,05$. Additionally Average full collinearity VIF (AFVIF) as an indicator of multicollinearity should $<5$. For it can be shown in the following table: 
Table 2. Goodness of fit model

\begin{tabular}{ll}
\hline \multicolumn{1}{c}{ Measurement } & \multicolumn{1}{c}{ Model Results } \\
\hline Average path coefficient (APC) & $=0.403, \mathrm{P}<0.001$ \\
Average R-squared (ARS) & $=0.806, \mathrm{P}<0.001$ \\
Average adjusted R-squared (AARS) & $=0.802, \mathrm{P}<0.001$ \\
Average block VIF (AFVIF) & $=3.627$, acceptable if $<=5$ \\
Average full collinearity VIF (AFVIF) & $=3.975$, acceptable if $<=5$ \\
\hline
\end{tabular}

The results showed that the test results of the Goodness of fit model total (Average path coefficient (APC), Average R-squared (ARS), average adjusted R-squared (AARs), Average block VIF (AFVIF), Average full collinearity VIF (AFVIF)) have been met (Kock, 2011).

\subsection{Validity and Reliability Construct}

Table 3. Combined Loading and cross-loadings

\begin{tabular}{cccccccc}
\hline Indicators & $\mathrm{FC}$ & $\mathrm{NFC}$ & $\mathrm{PRO}$ & $\mathrm{PRF}$ & $\begin{array}{c}\text { Type (as } \\
\text { defined })\end{array}$ & SE & P value \\
\hline $\mathrm{X}_{11}$ & $(0.875)$ & 0.200 & -0.179 & 0.224 & Reflective & 0.076 & $<0.001$ \\
$\mathrm{X}_{12}$ & $(0.782)$ & 0.551 & -0.757 & 0.440 & Reflective & 0.078 & $<0.001$ \\
$\mathrm{X}_{13}$ & $(0.865)$ & -0.072 & 0.305 & -0.248 & Reflective & 0.076 & $<0.001$ \\
$\mathrm{X}_{14}$ & $(0.829)$ & -0.656 & 0.585 & -0.393 & Reflective & 0.077 & $<0.001$ \\
$\mathrm{X}_{21}$ & 0.087 & $(0.944)$ & -0.076 & -0.104 & Reflective & 0.074 & $<0.001$ \\
$\mathrm{X}_{22}$ & -0.087 & $(0.924)$ & -0.119 & 0.320 & Reflective & 0.075 & $<0.001$ \\
$\mathrm{X}_{23}$ & -0.002 & $(0.918)$ & 0.197 & -0.215 & Reflective & 0.075 & $<0.001$ \\
$\mathrm{Y}_{11}$ & -0.252 & 0.043 & $(0.833)$ & 0.107 & Reflective & 0.077 & $<0.001$ \\
$\mathrm{Y}_{12}$ & -0.661 & 0.156 & $(0.762)$ & 0.667 & Reflective & 0.078 & $<0.001$ \\
$\mathrm{Y}_{13}$ & -0.480 & 0.243 & $(0.637)$ & 0.291 & Reflective & 0.081 & $<0.001$ \\
$\mathrm{Y}_{14}$ & 0.144 & 0.192 & $(0.851)$ & -0.588 & Reflective & 0.076 & $<0.001$ \\
$\mathrm{Y}_{15}$ & 1.244 & -0.656 & $(0.721)$ & -0.393 & Reflective & 0.079 & $<0.001$ \\
$\mathrm{Z}_{11}$ & -0.580 & 0.160 & 0.226 & $(0.856)$ & Reflective & 0.076 & $<0.001$ \\
$\mathrm{Z}_{12}$ & 0.224 & 0.082 & 0.334 & $(0.840)$ & Reflective & 0.076 & $<0.001$ \\
$\mathrm{Z}_{13}$ & 0.359 & -0.239 & -0.549 & $(0.862)$ & Reflective & 0.076 & $<0.001$ \\
\hline
\end{tabular}

Outer Measurement model or models of construct validity and reliability. This output is used investigators to report the test results of the convergent validity of the measurement instrument. In Table 3 Combined Loading and cross-loadings, overall construct validity has met convergent validity $<0.70$ (p-value $<0.05)$. The assay results in Table 3 show that the convergent validity criteria are met in model 1 having already qualified, convergent validity 
of $>0.70$ and significant ( $\mathrm{p}$-value $<0.05$ ) so that it can continue to be analyzed. (Hair et al., 2013).

\subsection{Test of Discriminant Validity}

Discriminant validity is evidenced by the results of latent variable output correlations. This output reports the correlation coefficient between the latent variables. The criteria used are the square roots average variance extracted (AVE) is a column diagonal bracketed must be higher than the correlation between latent variables in the same column (above or below) (Sholihin \& Dwi, 2013).

Table 4. Correlations among 1.vs. with sq. rts. of Aves

\begin{tabular}{ccccc}
\hline Indicators & FC & NFC & PRO & PRF \\
\hline FC & $(0.839)$ & 0.807 & 0.768 & 0.687 \\
NFC & 0.807 & $(0.929)$ & 0.713 & 0.620 \\
PRO & 0.768 & 0.713 & $(0.865)$ & 0.862 \\
PRF & 0.687 & 0.620 & 0.862 & $(0.883)$ \\
\hline
\end{tabular}

The table shows that the discriminant validity have been met, it can be seen from the root of AVE on the diagonal column is greater than the correlation between constructs in the same column. The results have indication of the fulfilment of criteria for the discriminant validity.

\subsection{Reliability Construct}

Reliability construct test results can be shown with latent variable output coefficient, as in the following table:

Table 5. Latent variable standardized coefficients

\begin{tabular}{lllll}
\hline \multicolumn{1}{c}{ Measurement } & FC & NFC & PRO & PRF \\
\hline R-squared coefficients & & & 0.662 & 0.950 \\
Adjusted R-squared coefficients & & & 0.656 & 0.948 \\
Composite reliability coefficients & 0.904 & 0.950 & 0.874 & 0.889 \\
Cronbach's alpha coefficients & 0.859 & 0.920 & 0.819 & 0.812 \\
Average variances extracted & 0.703 & 0.863 & 0.585 & 0.727 \\
Full collinearity VIFs & 2.677 & 2.054 & 2.246 & 2.925 \\
Q-squared coefficients & & & 0.664 & 0.757 \\
Minimum & -2.177 & -2.425 & -1.923 & -2.265 \\
maximum & 1.658 & 1.815 & 2.124 & 2.311 \\
Medians & 0.149 & 0.247 & -0.178 & -0.171 \\
modes & 0.390 & 0.275 & -0.178 & 0.197 \\
Skewness & -0.099 & -0.109 & 0.487 & 0.342 \\
exc. kurtosis & -0.860 & -0.693 & -0.403 & 0.018 \\
\hline
\end{tabular}


Coefficient of determination (R-squared) that shows what percentage of the variance of the construct of an endogenous/criterion can be explained by the hypothetical constructs (Hasanuddin \& Sjahruddin, 2017). The higher the R-squared shows a good model. From the results of latent variable output coefficient R-squared shows the professionalism of 0,656 meaning variable professionalism variance can be explained by $65.60 \%$ by the variance of financial compensation and non-financial compensation, while the R-squared to construct faculty performance of 0.950 indicates that the variance can be explained by the performance of auditors $95.00 \%$ by variance professionalism.

Reliability composite value and have qualified cronbach alpha reliability that is $>0.70$. Output in the table indicates that the Average Variance Extracted (AVE) $>0.50$, which means meets the requirements of convergent validity (Sholihin, A \& Dwi. R, 2013). Full collinearity VIF is full of colinearity test results which include vertical and lateral multicollinearity. Lateral colinearity is colinearity between the latent variables predictor with the criterion. Colinearity lateral often overlooked when can cause the results to be biased. Full collinearity in the study VIF value is lower than 3.3 it indicates that the model is free from the problem of vertical or lateral colinearity and commond method bias. (Kock, 2013). Q-squared is a measure of non-parametric obtained through the algorithm blindfolding and used to study the predictive validity or relevance of a set of latent predictor variables on criterion variables. The output shows Q-squared is greater than zero, namely 0.664 and 0.757 means that the estimated model shows a good predictive validity. Overall, the result of measurement models (outer model) reflective construct has met the testing requirements of the Reliability constructs (Sholihin, A \& Dwi R, 2013).

\subsection{Hypothesis Testing}

Table 6. Standardized coefficients on path and P-value

\begin{tabular}{ccccccccc}
\hline \multicolumn{3}{c}{ Path coefficients } & \multicolumn{3}{c}{ P values } \\
\hline Variables & FC & NFC & PRO & PRF & FC & NFC & PRO & PRF \\
FC & & & & & & & \\
NFC & & & & $<0.001$ & $<0.001$ & \\
PRO & 0.509 & 0.336 & & & 0.005 & 0.060 & $<0.001$ \\
PRF & 0.237 & 0.143 & 0.789 & & & & \\
\hline
\end{tabular}

Hypothesis testing results showed that, among the five (5) causality between variables (direct effect) are built in this model, there is one which rejects the hypothesis that the effect of financial compensation on lecturers performance of the $p$-value $=0.060>0.05$.

On other for testing the effect of indirect (mediator variable effect) carried out by using test Sobel approach computing sobel test of mediation for Baron \& Kenny Approach (Baron \& Kenny, 1986), can be shown as follows: 
Table 7. Sobel test of financial compensation on lecturer's performance: as a mediating effect of professionalism

\begin{tabular}{ccccc}
\hline$\underline{\mathrm{B}}$ & $\underline{\mathrm{SE}}$ & $\underline{\beta}$ & Results & \\
\hline 0,173 & 0,089 & 0,237 & Indirect Effect $(\mathrm{a} \cdot \mathrm{b})=$ & 0,276 \\
\hline 0,404 & 0,083 & 0,509 & Sobel's SE $=\sqrt{ }[(\mathrm{a} \cdot \mathrm{SEb}) 2+(\mathrm{b} \cdot \mathrm{SEa}) 2]=$ & 0,065 \\
\hline 0,683 & 0,077 & 0,789 & $Z=$ Indirect Effect $\div$ Sobel's $S E=$ & 4,267 \\
\hline \multicolumn{7}{c}{$c$} & & $p=$ & 0,000 \\
\hline & & & Standardized Indirect Effect $=(\beta \mathrm{a} \cdot \beta \mathrm{b})=$ & 0,402 \\
\hline & & Portion of $(\mathrm{X} \rightarrow \mathrm{Y})$ due to $\mathrm{M}=\left(\mathrm{c}-\mathrm{c}^{\prime}\right) / \mathrm{c}=$ & $100,00 \%$ \\
\hline
\end{tabular}

The table shows that the mediating role of professionalism in analyzing the effect of financial compensation on lecturer's performance is proven to give positive and significant effect $\alpha=$ $0,000<0,05$ with path coefficient value of 0,402 .

Table 8. Sobel test effect of non financial compensation as a mediating the professionalism on lecturers performance

\begin{tabular}{ccccc}
\hline$\underline{\mathrm{B}}$ & $\underline{\mathrm{SE}}$ & $\underline{\beta}$ & \multicolumn{2}{l}{ Results } \\
\hline 0,094 & 0,091 & 0,143 & Indirect Effect $(\mathrm{a} \cdot \mathrm{b})=$ & 0,176 \\
\hline 0,258 & 0,087 & 0,336 & Sobel's SE $=\sqrt{[(\mathrm{a} \cdot \mathrm{SEb}) 2+(\mathrm{b} \cdot \mathrm{SEa}) 2]=}$ & 0,063 \\
\hline 0,683 & 0,077 & 0,789 & $Z=$ Indirect Effect $\div$ Sobel's SE $=$ & 2,812 \\
\hline & & & $p=$ & 0,005 \\
\hline & $c=a b+c^{\prime}$ & & Standardized Indirect Effect $=(\beta \mathrm{a} \cdot \beta \mathrm{b})=$ & 0,265 \\
\hline & & Portion of $(\mathrm{X} \rightarrow \mathrm{Y})$ due to $\mathrm{M}=\left(\mathrm{c}-\mathrm{c}^{\prime}\right) / \mathrm{c}=$ & $100,00 \%$ \\
\hline
\end{tabular}

The table shows that the mediating role of professionalism in analyzing the effect of non financial compensation on the lecturer performance is proven to give has a positive and significant effect $\alpha=0,005<0,05$ path coefficient value of 0,265 .

\section{Discussion}

\subsection{Linking of financial compensation on the Lecturer's Professionalism}

The effect of financial compensation on lecturer's professionalism can be evidenced by standardized path coefficients (beta/a standardized path coefficient) amounted to 0,509 with a positive direction. Beta/a standardized path coefficient are positive, explaining that financial compensation can increase the professionalism of the lecturers. Then it can be proven with p-value $=0.001<0.05$. Hypothesis testing results prove that the financial compensation is positive and significant effect on lecturer's professionalism, it can be concluded that a high financial compensation and the direction of the real against the increased lecturer's professionalism, so the hypothesis $\left(\mathrm{H}_{1}\right)$ financial compensation has a positive and significant effect on lecturers professionalism proved to be accepted or supported by empirical facts. 
A significant result due to the faculty felt that the salary they earn is now in accordance with their expectations so can be improve the attitude of lecturers to be able to be a good example for behaviour for the people around them and comply with the existing rules in various condition to carry out its obligations as lecturers as well as to improve the quality of students and have the desire to keep a lecturer with the amount of salary receipt as obtained today. The statement is relevant to the results of previous studies, that the financial compensation providing a positive effect on the professionalism (Nzulwa, 2015; Tanjung, 2015). This study rejected the findings explaining that the compensation system: (1) leads to job behaviours dysfunctional, (2) make the work behaviour functionally ineffective and even discourage it, (3) are focused on the work of each employee compared to strengthen cooperation between employees and (4) making employees is difficult to have the perception that a clear and unambiguous to the relationship between the performance of the award he received, (5) although it is intended to pay for performance, but in reality intended to pay employee attendance, (6) directing employees to conduct behaviour which they believe will enable it received an award, because such behaviour often does not correspond to the desired by the leadership (Kerr, 1975).

\subsection{Linking of Non Financial Compensation on Lecturer'S Professionalism}

The effect of non financial compensation on lecturer's professionalism demonstrated by standardized path coefficients (beta/a standardized path coefficient) of 0.336 with a positive direction. Beta/a standardized path coefficient are positive, explaining that the non financial compensation can be increase lecturer's professionalism. Then it can be proven with p-value $=0.001<0.05$. The test results prove the hypothesis that non financial compensation has a positive and significant effect on lecturer's professionalism, it can be concluded that a high non financial compensation and the direction of the real against the increased lecturer's professionalism, so the hypothesis $\left(\mathrm{H}_{2}\right)$ non financial compensation positive and significant effect on lecturer's professionalism can be proved to be accepted or supported by empirical facts.

The findings of this study explains that significant influence due during the award becomes a lever lecturer in improving the quality of work, and the establishment of harmonization among lecturers are caused by the desire for mutual respect between fellow lecturers as well as the commitment of the government to provide equal opportunities to lecturers to gain an appreciation that these conditions give real effect to the desire of lecturers to improve the quality of students and to keep a lecturer and wants lecturers to constantly make improvements behaviour so that it can be a good example and adhere to all forms of legislation that has been set by the government and universities.

The results of this study support the notion that the non financial compensation is an award that focuses on the need for employees to get a rate that varies in achievement, recognition, responsibility, influence and self-development (Armstrong, 1999). Consist of the findings on previous researchers that the compensation has a positive effect on professionalism (Tanjung, 2015; Nzulwa, 2015). 


\subsection{Linking of Financial Compensation on Lecturer'S Performance}

The effect of financial compensation on the lecturers performance can be evidenced by the path coefficients standardized (beta/a standardized path coefficient) of 0.237 with directions positive. Beta/a standardized path coefficient are positive, explaining that financial compensation can be increase lecturer's performance. Then it can be proven with a p-value = $0,005<0,05$. the test results prove the hypothesis that financial compensation has a positive and significant effect on lecturer's performance, it can be concluded that a high of financial compensation in the same direction and real improvement on lecturer's performance, so that the hypothesis $\left(\mathrm{H}_{3}\right)$ financial compensation has a positive and significant effect on lecturer's performance proved to be accepted or supported by empirical facts.

A significant result due to benefit from the provision of health insurance and old-age or the same thing and felt a lecturer at this time is very helpful lecturer in lightening the burden of the family so that they are more focused in doing so contributes to the high desire of lecturers to participate in the activities undertaken by the universities and other parties and lecturers always take advantage of the sponsorship research funding and a high desire faculty to conduct research in cooperation with the relevant parties. The results of this study support the notion that the compensation was the main reason for most people looking for work Meeting the needs of both financial and non financial popularity has become a motivation of each individual in doing the job he does (Riva, 2011). Money is still a status symbol for most people because it reflects of power and prestige, money can demonstrate one's success to the community (Hern \& Alonzo, 1998). This study supports the findings of previous investigators that a compensation is significant effect on lecturer's performance (Surbakti, 2011). Benefits of certification, education and training simultaneously affect performance improvement and lecturer's performance (Sofyan, 2012). Extrinsic compensation more favourable for such compensation leads to other compensation, for example, a big salary will lead to the achievement and improvement of social status (Hackman \& Suttle, 1977). The compensation given to an individual may increase toward the higher performance (Peterson \& Luthans, 2006; Yousaf et al., 2014).

\subsection{Linking of Non Financial Compensation on Lecturer's Performance}

Non financial compensation effect on lecturer's performance can be demonstrated by standardized path coefficients (beta/a standardized path coefficient) of 0,143 with a positive direction. Beta/a standardized path coefficient are positive, explaining that the non financial compensation can be increased lecturer's performance. Then it can be proven with $\mathrm{p}$-value = $0,060>0.05$. The test results prove the hypothesis that non-financial compensation has a positive and insignificant effect on lecturer's performance, it can be concluded that a high financial compensation in the same direction but no significant effect on improving the lecturer's performance, so the hypothesis $\left(\mathrm{H}_{4}\right)$ non financial compensation have a positive and significant effect on lecturer's performance is not proven or cannot be supported by empirical facts.

Lecturers have equal opportunities in terms of promotion because promotion is at work, but these conditions have not been able to encourage faculty to produce scientific papers each 
semester and increase the ability of professors to act as keynote speakers and lecturer's low ability to conduct research publications in journals of repute. This condition is a cause of non-financial compensation has a positive and insignificant effect on lecturer's performance. The findings of this study have denied the claims Armstrong (1999), that one of the advantages of non financial compensation compared with the financial compensation is a nonfinancial compensation can be a very effective tool for organizations to improve individual performance. Disputing the findings Stajkovic \& Luthan (2000) that the social reward and performance feedback significantly improves performance relatively higher than the salary. Disputing the findings of other researchers, that the provision of non financial compensation can be increased performance (Akhter et al., 2016).

\subsection{Linking of Professionalism on Lecturer's Performance}

Professionalism effect on lecturer's performance can be demonstrated by standardized path coefficients (beta/a standardized path coefficient) of 0,789 with a positive direction. Beta/a standardized path coefficient is positive, explaining that the high professionalism of the lecturers that can be increased the lecturer's performance. Then it can be proven with p-value $=0,001<0,05$. Hypothesis testing results prove that professionalism has a positive and significant effect on lecturer's performance, it can be concluded that the high professionalism of the lecturers in the same direction and real improvement the lecturer's performance, so that the hypothesis $\left(\mathrm{H}_{5}\right)$ professionalism has a positive and significant effect on lecturer's performance proven or can be supported by empirical facts.

Lecturer contributions sufficient to contribute ideas to improve the management of colleges and support for higher education to the creation of the quality of their work lecturers have a significant impact on the involvement of lecturers in society and the ability of lecturers in doing teaching in a timely and complete course materials in accordance with government regulations and colleges cause lecturer's professionalism significant on lecturer's performance. This study supports the findings of some previous researchers that the increasing professionalism will have a significant effect on performance (Kwon et al., 2010; Dali \& Mas'ud, 2014). Lecturer's professionalism consisting of bachelor's degree, licensure, or in other words is lecturers certified and job tenure showed a significant relationship with student achievement. Professionalism and performance go hand in hand and they stated that one of the hallmarks of any profession is the commitment of its members to a code of conduct that sets values and professional responsibility (Darling-Hammond, 2000; Wayne \& Youngs, 2003).

\subsection{Financial Compensation on Lecturer's Performance: As a Mediating Effect of Professionalism}

The effect of financial compensation on lecturer's performance: as a mediating effect of professionalism can be demonstrated by standardized path coefficients (beta/a standardized path coefficient) of 0,402 with a positive direction. Beta/a standardized path coefficient are positive, explaining that financial compensation through high professionalism of the lecturers that can be increased lecturer's performance. Then it can be proven with $p$-value $=0,000<0$, 05. Hypothesis testing results prove that financial compensation on lecturer's performance: as 
a mediating effect of professionalism has a positive and significant effect, it can be concluded that the financial compensation through the high professionalism of lecturers in the same direction and real improvement lecturer's performance, so that the hypothesis $\left(\mathrm{H}_{6}\right)$ financial compensation as a mediated professionalism is positive and significant effect on lecturer's performance can be supported by empirical facts.

\subsection{Non Financial Compensation on Lecturer's Performance: As a Mediating Effect of Professionalism}

The effect of non financial compensation as a mediated the professionalism on lecturer's performance can be demonstrated by standardized path coefficients (beta/a standardized path coefficient) amounted to 0,265 with a positive direction. Beta/a standardized path coefficient are positive, explaining that the non financial compensation through high professionalism of the lecturers that can be increased lecturer's performance. Then it can be proven with p-value $=0,005<0,05$. The test results prove the hypothesis that the non financial compensation as a mediated professionalism has a positive and significant effect on lecturer's performance, it can be concluded that non financial compensation as a mediated the high professionalism of lecturers in the same direction and real improvement on lecturer's performance, so that the hypothesis $\left(\mathrm{H}_{7}\right)$ non financial compensation as a mediated professionalism has a positive and significant effect on lecturer's performance proven or can be supported by empirical facts.

\section{Conclusions and Recommendations}

Financial compensation has a positive and significant effect on the lecturers professionalism, due to the salary they earn is now in accordance with their expectations so can be improve the attitude of lecturers to be able to be a good example for behaviour for the people around them and comply with the existing rules in various conditions to its obligations as a lecturer and to improve the quality of students and have the desire to keep a lecturer.

Non financial compensation positive and significant effect on the lecturers professionalism, the findings of this study explains that significant influence due during the award becomes a lever lecturer in improving the quality of work, and the establishment of harmonization among lecturers are caused by the desire for mutual respect among the lecturer as well as a lack of commitment government to provide equal opportunities to lecturers to gain an appreciation that these conditions give real effect to the desire to improve the quality faculty and students to keep a lecturer and faculty desire to continually make improvements so that the behaviour can be a good example.

Financial compensation positive and significant effect on lecturer's performance, due to the benefits of the provision of health insurance and old-age or the same thing and felt a lecturer at this time is very helpful lecturer in lightening the burden of the family so that they are more focused in doing so contributes to the high desire of lecturers to participate in the activities carried out by the universities or other parties and lecturers always take advantage of the sponsorship research funding and a high desire faculty to conduct research in cooperation with the relevant parties.

Non-financial compensation have a positive and insignificant effect on lecturer's 
performance the condition is caused due to lecturers have equal opportunities in terms of promotion because promotion is at work, but these conditions have not been able to encourage faculty to produce scientific papers each semester and increase the ability of professors to act as keynote speaker and low ability of professors to conduct research publications in journals of repute.

Professionalism positive and significant effect on lecturer's performance, contributing lecturer sufficient to contribute ideas to improve the quality of university management and the ability of lecturers in doing teaching in a timely and complete course materials in accordance with government regulations and higher education into the causes of the significant influence of professionalism in the lecturers performance.

This study provides recommendations to the lecturers to improve their knowledge and abilities so that faculty can do your research well and then are able to do the publication of the research results in international journals of repute. Universities are expected to continue to increase support for faculty in both the financial and non financial context, so that lecturer's can continuously improve the professionalism and lecturer's performance.

\section{References}

Akhter, N., Ijaz, M., Siddiqi, U. I., Shouqat, U., \& Raza, A. (2016). Impact of Compensation Discrimination on Employees Performance in Engro Food Limited, Alhamd Food Limited and Leader industry Sahiwal of Pakistan. International Review of Management and Business Research, 5(2), 547

Alam, S. (2015). Effects of Conflict Mediation Role and Ambiguity Role in Leadership and Communications to Organizational Commitment and Performance of Private Higher Education Lecturers in Makassar. Doctoral Program of Economics and Business Sciences Hasanuddin University. Makassar

Angrist, J. D., \& Acemoglu, D. (2001). Consequences of Employment Protection? The Case of the Americans with Disabilities Act. MIT. USA

Armstrong, M. (1999). Hand Book of Human Resource Management Practice (7th ed.). London; Kogan Page Ltd.

Arwildayanto. (2013). Human Resource Management Higher Education Cultural Approach Professional Lecturer. Alfa Beta Bandung.

Baron, R. M., \& Kenny, D. A. (1986). The moderator-mediator variable distinction in social psychological research: Conceptual, strategic and statistical considerations. Journal of $\begin{array}{lrrrr}\text { Personality } \quad \text { and Social } & \text { Psychology, 51, }\end{array}$ https://doi.org/10.1037/0022-3514.51.6.1173

Bellois, D. (2003). The role of professional code in work performance. Journal of Management Sciences, 6(11), 41-59.

Borman, W. C., \& Motowidlo, S. M. (1993). Expanding the criterion domain to include elements of contextual performance. Personnel Selection in Organizations; San Francisco: 
Jossey-Bass, 71.

Boyt, T. E., Lusch, R. F., \& Naylor, G. (2001). The role of professionalism in determining job satisfaction in professional services: A study of marketing researchers. Journal of Service Research, 3(4), 321-330. https://doi.org/10.1177/109467050134005

Burki, S. J., Perry dan, G. E., \& Dillinger, W. R. (1999). Beyond the Center: Dezentralizing the State. The World Bank, Washington DC

Dali, N., \& Mas'ud, A. (2014). The Impact of Profesionalism, Locus of Control, and Job Satisfaction on Auditors' Performance: Indonesian Evidence. International Journal of Bussiness and Management Invention, 3, 63-73.

Dali. Nasrullah, Armanu, Margono Setiawan \& Solimun, (2013). Professionalism and Locus of Control Influence on Job Satisfaction Moderated By Spirituality at Work and Its Impact on Performance Auditor. International Journal of Business and Management Invention, 2(10). $1-11$.

Darling-Hammond, L. (2000). Teacher quality and student achievement. Education policy analysis archives, 8,1 . https://doi.org/10.14507/epaa.v8n1.2000

Dessler, G. (1998). Human Resource Management (vol. 2). Prenhallindo, Jakarta

Gibbs, B. (1994). Professionalism: The first ethical code. Career management journal, 16, 171-184.

Hackman, J. R., \& Suttle, J. L. (1977). Work design. Improving life at work: Behavioral science approaches to organizational change.

Hair, J. F., Hult, G. T. M., Ringle, C. M., \& Sarstedt, M. (2013). A Primer on Partial Least Squares Structural Equation Modeling (PLS-SEM). Thousand Oaks: Sage

Hall, R. (1968). Professionalism and bureaucratization. American Sociological Review, 33, 92-104. https://doi.org/10.2307/2092242

Hameed, A., Ramzan, M., \& Zubair, H. M. K. (2014). Impact of compensation on employee performance (empirical evidence from banking sector of Pakistan). International Journal of Business and Social Science, 5(2).

Harefa, A. (1999). Awakening the Spirit of Professionalism. Jakarta: Gramedia

Hasanuddin, R., \& Sjahruddin, H. (2017). The Structure of Emotional Intelligence, Spiritual Intelligence and Its Relationship with Work Enthusiasm and Auditor Performance. World Journal of Business and Management, 3(1), 67. https://doi.org/10.5296/wjbm.v3i1.11321

Kalbers, L. P., \& Fogarty, T. J. (1995). Professionalism and its consequences: A study of internal auditors. Auditing, 14(1), 64.

Kaplan, L. S., \& Owings, W. A. (2001). Teacher quality and student achievement: Recommendations for principals. NASSP bulletin, 85(628), 64-73. https://doi.org/10.1177/019263650108562808 


\section{Macrothink}

Journal of Asian Development

ISSN 2377-9594

2017, Vol. 3, No. 2

Kerr, S. (1975). On the folly of rewarding A, while hoping for B, Academy of Management Journal, 18(4), 769-83. https://doi.org/10.2307/255378

Kock, N. (2010). Using e-collaboration WarpPLS in studies: An overview of the main five analysis steps. International Journal of e-Collaboration (IJEC), 6(4), 1-11. https://doi.org/10.4018/jec.2010100101

Kock, N. (2011). Using e-collaboration WarpPLS in studies: Descriptive statistics, settings, and key analysis results. International Journal of e-Collaboration, 7(2), 1-17. https://doi.org/10.4018/jec.2011040101

Kock, N. (2013). Using WarpPLS in E-Collaboration Studies: Descriptive Statistics, Settings. Interdisciplinary Applications of Electronic Collaboration Approaches and Technologies, 62.

https://doi.org/10.4018/978-1-4666-2020-9.ch005

Kwon, K. J., Ko, K. H., Kim, K. W., \& Kim, J. A. (2010). The impact of nursing professionalism on the nursing performance and retention intention among psychiatric mental health nurses. Journal of Korean Academy of Nursing Administration, 16(3), 229-239. https://doi.org/10.11111/jkana.2010.16.3.229

Luthans, Fred, (2005). Organizational Behavior (10 ${ }^{\text {th }}$, ed,), Translated by: Vivin Andhika Yuwono; Shekar Purwanti; Th. Arie Prabawati; And Winong Rosari.Perb Publisher Andi, Yogyakarta.

Mondy, R. W. (2008). Human Resource Management (Vol. 1, $10^{\text {th }}$, ed.). Erlangga, Jakarta.

Nyström, S. (2009). The dynamics of professional identity formation: Graduates' transitions from higher education to working life. Vocations and Learning, 2(1), 1-18. https://doi.org/10.1007/s12186-008-9014-1

Nzulwa, J. (2014). Motivational Factors Affecting High School Teachers' Professional Conduct and Work Performance: A Case of Public High Schools in Nairobi City. International Journal of Humanities and Social Science, 4(3), 60-66.

Omenn Strunk, K., \& Robinson, J. P. (2006). Oh, won't you stay: A multilevel analysis of the difficulties in retaining qualified teachers. Peabody Journal of Education, 81(4), 65-94. https://doi.org/10.1207/s15327930pje8104_4

Peterson, S. J., \& Luthans, F. (2006). The impact of financial and nonfinancial incentives on business-unit outcomes over time. Journal of applied Psychology, 91(1), 156. https://doi.org/10.1037/0021-9010.91.1.156

Republic of Indonesia. (2005). Law of the Republic of Indonesia number 14 of 2005 on Teachers and Lecturers. State Secretariat. Jakarta

Rivai, V. (2011). Human Resource Management for Companies from Theory to Practice. PT. Rajagrafindo Persada, Jakarta.

Rusydi, M. (2014). Influence Leadership and Empowerment to Competence and Job 
Performance. Doctoral Program of Economics Faculty of Economics and Business Universities Hasanuddin. Makassar.

Schmidt, F. L., \& Hunter, J. E. (1998). The validity and utility of selection methods in personnel psychology: Practical and theoretical implications of 85 years of research findings. Psychological bulletin, 124(2), 262. https://doi.org/10.1037/0033-2909.124.2.262

Sholihin, M., \& Dwi, R. (2013). SEM-PLS with WarpPLS 3.0. Andi. Yogyakarta

Sofyan, A. (2012). Analysis of the Effect of Grant Allowance Certification and Education and Training of Lecturer Performance Improvement and Performance Faculty at University of North Sumatra. Graduate School of University of North Sumatra.

Stajkovic, A. D., \& Luthans, F. (2003). Behavioral management and task performance in organizations: conceptual background, meta - analysis, and test of alternative models. Personnel Psychology, 56(1), 155-194. https://doi.org/10.1111/j.1744-6570.2003.tb00147.x

Surbakti, A. (2011). Influence Analysis of Compensation, Training and Motivation on Performance Lecturer at Computer Science High School (STIKOM) Medan (Doctoral dissertation).

Tanjung, B. N. (2015) the Effect of Principal Leadership, Compensation, and Work Motivation on Teacher Professionalism at Private High Schools in Medan. IOSR Journal of Humanities and Social Science (IOSR-JHSS), 20(5).

Thompson, A. A., \& Strickland, A. J. (2001). Strategic management: Concepts and cases. McGraw-Hill/Irvin.

Uno, H. B., \& Lamatenggo, N. (2012). The theory of performance and measurement. Jakarta: Bumi Aksara.

Wayne, A. J., \& Youngs, P. (2003). Teacher characteristics and student achievement gains: A $\begin{array}{llll}\text { review. Review of Educational research, } & \text { 73(1), }\end{array}$ https://doi.org/10.3102/00346543073001089

Whitmore, J. (1997). Coaching Performance. Jakarta : Gramedia Pustaka. Utama

Yousaf, A., Yang, H., \& Sanders, K. (2015). Effects of intrinsic and extrinsic motivation on task and contextual performance of Pakistani professionals: the mediating role of commitment foci. Journal of Managerial Psychology, 30(2), 133-150. https://doi.org/10.1108/JMP-09-2012-0277

\section{Copyright Disclaimer}

Copyright for this article is retained by the author(s), with first publication rights granted to the journal.

This is an open-access article distributed under the terms and conditions of the Creative Commons Attribution license (http://creativecommons.org/licenses/by/4.0/). 